geography to anthropology, are few in spite of the classical expeditions of Humboldt, Wallace, Bates and their successors. It includes the greater part of northern, central and western Brazil and parts of Bolivia, Colombia, Ecuador, Peru and Venezuela, and British, French and Dutch Guiana, and is conveniently called by Humboldt's name, the Hylean (forested) Amazon.

At the Belém meeting all the countries mentioned above were represented, mostly by experts in various fields, with the exception of the Netherlands; in addition, the United States sent Dr. Bassett, Maguire, of the New York Botanic Garden, and Dr. Remington Kellogg, of the Division of Mammals of the Smithsonian Institution. Dr. Fred L. Soper, of the PanAmerican Sanitary Bureau, best known for his work in the suppression of yellow fever in eastern South America, was elected president of the meeting; the secretary was Dr. E. J. H. Corner, for many years at the Botanical Gardens at Singapore and now principal field scientific officer for the United Nations Educational, Scientific and Cultural Organisation in Latin America, and his assistant was Dr. B. Malamos, a Greok specialist in tropical medicine. The conclusions reached at Belém will be considered at the next annual meeting of the United Nations Educational, Scientific and Cultural Organisation, to be held at Mexico City in November. In summary, they are that the scientific investigation of the Hylean region is well fitted for international collaboration and can scarcely be carried out in any other way; that science should be taken to include the social sciences as well as the physical and biological sciences and medicine; and that the next step, if an institute can be financed and its foundation is approved, is to set up a small body of experts to do full-time work on planning.

\section{British Bryological Society}

MEMBens of the British Bryological Society assembled at Kirriemuir, Angus, during September 3-10 for the annual general meeting and excursion. Under the leadership of Miss U. Duncan, excursions were made to the Sidlaw Hills, the Loch of Kinnordy, the Den of Airlie, Glen Clova and Barry Sands. Two days were devoted to the investigation of localities in Glen Clova; the first to Loch Brandy and the cliffs above, and the second day to the Fee Burn area. Small parties also went to Glen Isla and Glen Prosen. Many interesting bryophytes were studied, and the results of the field-work will be published in the next part of the Transactions of the Society. Mr. A. Thompson was elected president, with Dr. P. W. Richards as vice-president, for 1947-48. Mr. F. C. Wallace was elected honorary secretary.

\section{The Night Sky in October}

New moon occurs on Oct. 14d. 06h. 10m., U.T., and full moon on Oct. $29 \mathrm{~d} .20 \mathrm{~h} .07 \mathrm{~m}$. The following conjunctions with the moon take place: Oct. 8d. 2lh., Mars $4^{\circ}$ S. ; Oct. 9d. 22h., Saturn $5^{\circ}$ S. ; Oct. 16d. 04h., Mercury $4^{\circ} \mathrm{S}$; ; Oct. 17d. 05h., Jupiter $1^{\circ} \mathrm{N}$. In addition to these conjunctions with the moon, Mercury is in conjunction with Venus on Oct. $29 \mathrm{~d}$. 09h., Mercury being $2 \cdot 7^{\circ} \mathrm{S}$. Mercury and Venus are evening stars but set too soon after the sun for favourable observation. Mars, in the constellation of Cancer, can be seen during the morning hours, rising at $23 \mathrm{~h} .37 \mathrm{~m} ., 23 \mathrm{~h} .25 \mathrm{~m}$., and 23h. $09 \mathrm{~m}$, at the beginning, middle, and end of the month, respectively. Jupiter, in the constellation of
Scorpius, is visible only during the early portion of the night, setting at $19 \mathrm{~h} .17 \mathrm{~m} ., 18 \mathrm{~h} .29 \mathrm{~m}$., and 17h. $35 \mathrm{~m}$., at the beginning, middle, and end of the month, respectively, in the last case just an hour after sunset, and at this time it is very close to $\beta$ Scorpii. Saturn, in the constellation of Leo, cannot be seen until the early morning hours, rising at Ih. $26 \mathrm{~m}$., $0 \mathrm{~h} .38 \mathrm{~m}$., and $23 \mathrm{~h} .42 \mathrm{~m}$., at the beginning, middle, and end of the month, respectively, and can be easily identified by its position with reference to Regulus, of which it is a little west. An occultation of only one star brighter than magnitude 6 takes place : October 4 d. 3h. $17 \cdot 8 \mathrm{~m}$., 13 Tauri $(R)$, the latitude of Greenwich being assumed and $R$ referring to reappear. ance. The Orionid meteors are active from about October 18-26, but towards the end of this period moonlight will partly interfere with the observations. On October 26 the moon sets at $2 \mathrm{~h}$. $14 \mathrm{~m}$.

\section{Announcements}

THE Tilden Lecture of the Chemical Society will be delivered by Prof. E. G. Cox, professor of chemistry in the University of Leeds, in the Society's rooms on October 23; he will speak on "Crystallographic Technique and its Chemical Significance".

Mr. P. A. Wells, general secretary of the Society of Dyers and Colourists, has been appointed director of education in the International Wool Secretariat, London.

Dr. W. T. H. Williamson, director of the Agricultural Department of the British Council since its formation in 1945, has been appointed lecturer in charge of the newly established Department of Soil Science in the University of Aberdeen. During the War, Dr. Williamson was adviser in agricultural chemistry in the University College of South Wales, Monmouthshire. Previously, he was for eleven years chief chemist to the Ministry of Agriculture in Egypt.

Mr. B. J. MASON, of University College, Nottingham, has been awarded a Shirley fellowship by the British Cotton Industry Research Association. Mr. Mason will work under the direction of Prof. L. F. Bates and Dr. G. D. Yarnold at University College, Nottingham, on the hysteresis of the contact angle of liquids against solids, and will take up the fellow. ship immediately. The fellowship awarded in October 1946 to Mr. G. W. Ross, of the University of Aberdeen, has been extended for a further year. Mr. Ross is working on polymerization in the liquid phase under the direction of Prof. H. W. Melville.

ON September 16, at Bonneville Salt Flats, Utah, Mr. John Cobb set up a world speed record for motorears of $394 \cdot 196$ miles an hour.

The second general meeting of the Gesellschaft Deutscher Chemiker in der Britischen Zone will take place at Bonn during October 7-9. The advance programme is not yet available, but it is known that a wide range of chemical topics will be discussed. Accommodation for foreign guests in Bonn is severely limited; no further applications can be considered.

The Women's Legion and the Women's Engineering Society announce the foundation of a new scholarship in aeronautical engineering for women. It will be awarded every two years, girls between the ages of fifteen and twenty being eligible. Application forms, to be returned before April 30, 1948, can be obtained from the Secretary, Women's Engineering Society, 35 Grosvenor Place, London, S.W.1, to which all inquiries should be made. 